\title{
DISTRIBUTION OF RARE EARTH ELEMENTS IN METAMORPHIC ROCKS OF PLATTENKALK GROUP AT CENTRAL CRETE, GREECE
}

\author{
Stathogianni F. ${ }^{1}$, Manoutsoglou E. ${ }^{1}$, Staboliadis I. ${ }^{2}$, Pantelaki O. $^{2}$ and \\ Kallithrakas-Kontos N. ${ }^{1}$ \\ ${ }^{I}$ Technical University of Crete, School of Mineral Resources Engineering, University Campus, \\ GR-73100 Chania, Greece, emanout@mred.tuc.gr
}

\begin{abstract}
Within the metamorphic rocks of the Plattenkalk Group, in an occurrence at Tallaia Mountains, central Crete, light rare earth elements Cerium and Lanthanum are found. The studied rare earths are seen in an epidote group mineral, allanite. Scanning Electron Microscopy of the samples showed clearly the crystals of allanite (prekinematic crystals) and their grain size. Mineral processing was conducted for the size fractions: $(<10 \mu \mathrm{m}),(10-212 \mu \mathrm{m})$ and $(212-1000 \mu \mathrm{m})$, according to the magnetic properties and grain size of allanite. After magnetic separation of the fraction $(<10$ $\mu \mathrm{m})$ and (212-1000 $\mu \mathrm{m})$ rare earths Ce and La were observed to have higher concentrations in the magnetic products. In conclusion, (according to the microscopic and mineral processing data) the optimum grain size for the beneficiation of allanite is the size fraction $(10-212 \mu \mathrm{m})$.
\end{abstract}

Keywords: Cerium, Lanthanum, Allanite, Crete.

\section{Пєрі́ $\rceil \psi \eta$}

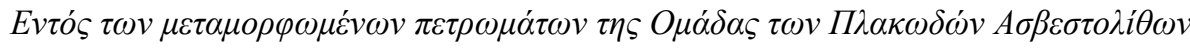

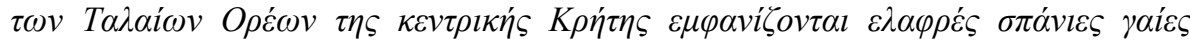

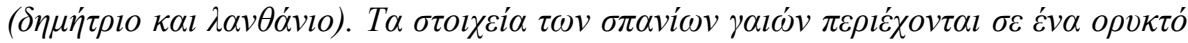

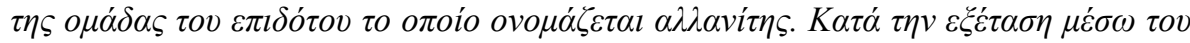

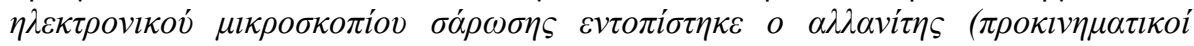

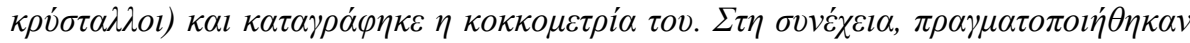

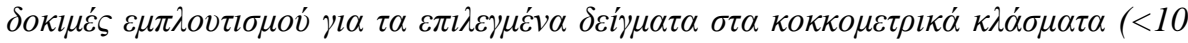

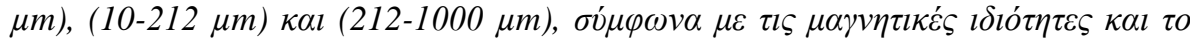

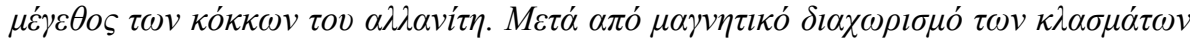

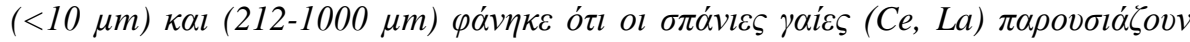

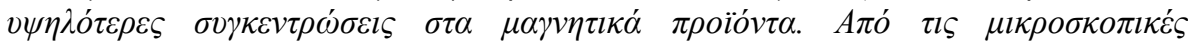

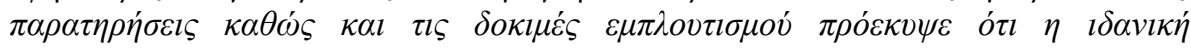

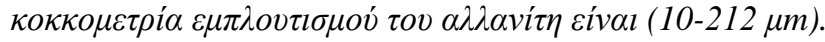

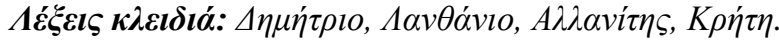

\section{Introduction}

Rare earth metals are used in the modern industry in numerous technological fields, such as catalysts, electronics, glasswork, ceramics, special alloys and superconductors. Recently, the application of rare earths has focused on various research purposes, like geochronology and geochemical mapping, 
which is considered to play an important role in environmental research, geological mapping and mineral resources research. In addition, rare earths are used as geochemical tracers for hydrological, hydrogeological and oceanographic researches.

Recently, accessory LREE (Light Rare Earth Elements) bearing minerals have been investigated in eastern Crete, Greece, in a sequence of Palaeozoic amphibolite facies metapelites which were overprinted by Alpine low-T metamorphism $\left(\sim 300^{\circ} \mathrm{C}\right)$. The series is dominated by $\mathrm{Al}$, Ca rich metapelite layers, which contain Palaeozoic allanite, secondary Alpine monazite with low Y contents $(<0.6 \mathrm{wt} . \%)$ or rhabdophane (Krenn and Finger, 2007). LREE-bearing minerals are also found within the metamorphic marine siliciclastic of Sisses and Fodele beds of the Plattenkalk Group (Manutsoglu, 2008). Mineral processing was conducted for the size fractions: $(<10 \mu \mathrm{m}),(10-212$ $\mu \mathrm{m})$ and $(212-1000 \mu \mathrm{m})$, according to the magnetic properties and grain size of allanite.

Table 1 - Occurrences of allanite in Greece (updated until 2009).

\begin{tabular}{|l|l|l|}
\hline Occurrence of allanite & Location & Author \\
\hline Accessory mineral in amphibolites & Samos & Mezger and Okrusch (1985) \\
\hline In andesitic rocks & Poros, NE Peloponnese & Mitropoulos P (1987) \\
\hline $\begin{array}{l}\text { Accessory mineral in Miocene I- } \\
\text { type granitoids }\end{array}$ & Cyclades & Henjes-Kunst et al. (1988) \\
\hline Accessory mineral in migmatites & Central Rhodope & Kotopouli et al. (1991) \\
\hline In skarn formation & Serifos, Cyclades & $\begin{array}{l}\text { Perdikatsis and Papastavrou } \\
\text { (1993) }\end{array}$ \\
\hline In granitoid rocks & Thessaly & Kotopouli et al. (2000) \\
\hline $\begin{array}{l}\text { Accessory mineral in Augen } \\
\text { migmatite }\end{array}$ & Naxos, Cyclades & Keay et al. (2001) \\
\hline Accessory mineral in quartz diorite & Delos, Cyclades & Pe-Piper et al. (2002) \\
\hline In metamorphic rocks & Ikaria, Cyclades & Iliopoulos I (2005) \\
\hline $\begin{array}{l}\text { In magmatic epidote of the Sithonia } \\
\text { pluton }\end{array}$ & Sithonia, Chalkidiki & Keramidas et al. (2005) \\
\hline In phengite-rich eclogite & Syros, Cyclades & Putlitz et al. (2005) \\
\hline In granodiorite & Tinos, Cyclades & Mastrakas N (2006) \\
\hline $\begin{array}{l}\text { Accessory mineral in tonalites and } \\
\text { granodiorites }\end{array}$ & Sithonia, Chalkidiki & Christofides et al. (2007) \\
\hline Accessory mineral in metapelites & Eastern Crete & Krenn and Finger (2007) \\
\hline In metapelites and metasandstones & Central Crete & Manutsoglu E (2008) \\
\hline Accessory mineral in mélange & Syros, Cyclades & Miller et al. (2009) \\
\hline Accessory mineral in granites & Fanos, Northern Greece & Šarić et al. (2009) \\
\hline In metapelitic garnets & $\begin{array}{l}\text { Rhodope, Northern } \\
\text { Greece }\end{array}$ & Mposkos et al. (2009) \\
\hline
\end{tabular}

The rare earths studied are seen in an epidote group mineral called allanite. Allanite occurs in metamorphic rocks between Sisses and Fodele beds of the Plattenkalk Group. There have been several references since the middle 80's about the allanite occurrences in Greece. Allanite occurs mainly as an accessory mineral in a variety of geological environments. Most of the studies are located at Cyclades (Aegean region). Allanite is found in skarn at Serifos, in migmatites at Naxos, in plutonic rocks at Delos, in eclogites and mélange rocks at Syros, in granodiorite at Tinos. Other occurrences of allanite are reported in metamorphic rocks from Ikaria, in amphibolites from Samos, in andesitic rocks from Poros, in metapelites from East Crete and in some areas in Northern Greece (in plutonite from Chalkidiki, in migmatites and gneiss from Rhodope, in granites from Fanos) and in granitoids from 
Thessalia (Table 1). The four-year (2009-2013) ProMine project (Arvanitidis and Goodenough, 2014) has provided a well documented knowledge base of Europe's non-energy raw material resource potential, which is completed by various research outcomes regarding LREE distribution patterns (e.g. Melfos and Voudouris, 2012 and Papadopoulos et al., 2015).

\section{Geological settings}

The Plattenkalk Group (Permian-Oligocene) represents the lowermost tectonic unit under a nappe pile of metamorphic and non metamorphic units of the External Hellenides and has undergone a prograde metamorphism ranging from anchimetamorphic to high pressure/low temperature facies conditions (Manutsoglu, 1990). The generally acceptable aspect for their depositional conditions has been derived from lithological comparisons with the succession of the Ionian Zone. It represents a transition from very shallow to deeper pelagic sedimentation. The older part of the Plattenkalk Group includes marine siliciclastic sediments and carbonates of late Permian to early Triassic age. These rocks are overlain conformably by a thick sequence of neritic carbonates with stromatolites of Upper Triassic-Liassic age. The next level comprises the sequence of platy limestones with bedded and nodular chert of JurassicEocene age, which corresponds to the «Posidonia Schist» and «Viglaes facies» of Ionian zone. The uppermost stratigraphic level includes the transitional beds to a siliciclastic succession known as «Vathia Beds» on Peloponnes and "Kalavros Beds" on Crete, of Upper Eocene-Oligocene age. The Plattenkalk Group has been metamorphosed during Oligocene-Miocene (Manutsoglu, 1990). The discovery of extended colonies of lithistid demosponges in the middle parts (Jurassic-Eocene) of the chert-bearing metamorphic platy limestones from the Taygetos Mountains on the Peloponnes to the Ida Mountains on Crete allows the deduction of the sedimentary depositional conditions (Manutsoglu, et al. 1995; Soujon et al., 1995 and Manutsoglu et al., 1998, 2003).

\section{Materials and Methods}

Five samples were collected from the study area (Figure 1), two metasandstones and three schists (calc-schist, yellow and white schist). Mineralogical study through powder X-Ray diffraction (XRD) of these samples showed no evidence of allanite (Table 2). Thin section microscopy study showed microcrystals of allanite within crystals of albite. Scanning electron microscopy of the samples showed clearly the crystals of allanite (pre-kinematic crystals) and their grain size (approximately 30-100 $\mu \mathrm{m})$ (Figure 2).

Table 2 - X-Ray Diffraction investigation of the initial samples.

\begin{tabular}{|c|c|c|c|c|c|c|c|c|}
\hline Sample & 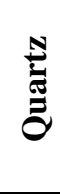 & $\stackrel{\frac{9}{0}}{\frac{0}{2}}$ & 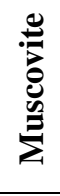 & : & 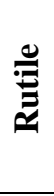 & 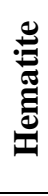 & $\stackrel{\varrho}{ٍ}$ & 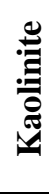 \\
\hline Metasandstone (1) & ++ & + & + & - & - & + & - & - \\
\hline Metasandstone (2) & ++ & + & + & - & + & - & - & - \\
\hline Schist (calc-schist) & + & - & + & ++ & + & - & + & - \\
\hline Schist (yellow) & ++ & + & + & - & + & - & - & - \\
\hline Schist (white) & ++ & + & ++ & + & - & - & - & + \\
\hline
\end{tabular}




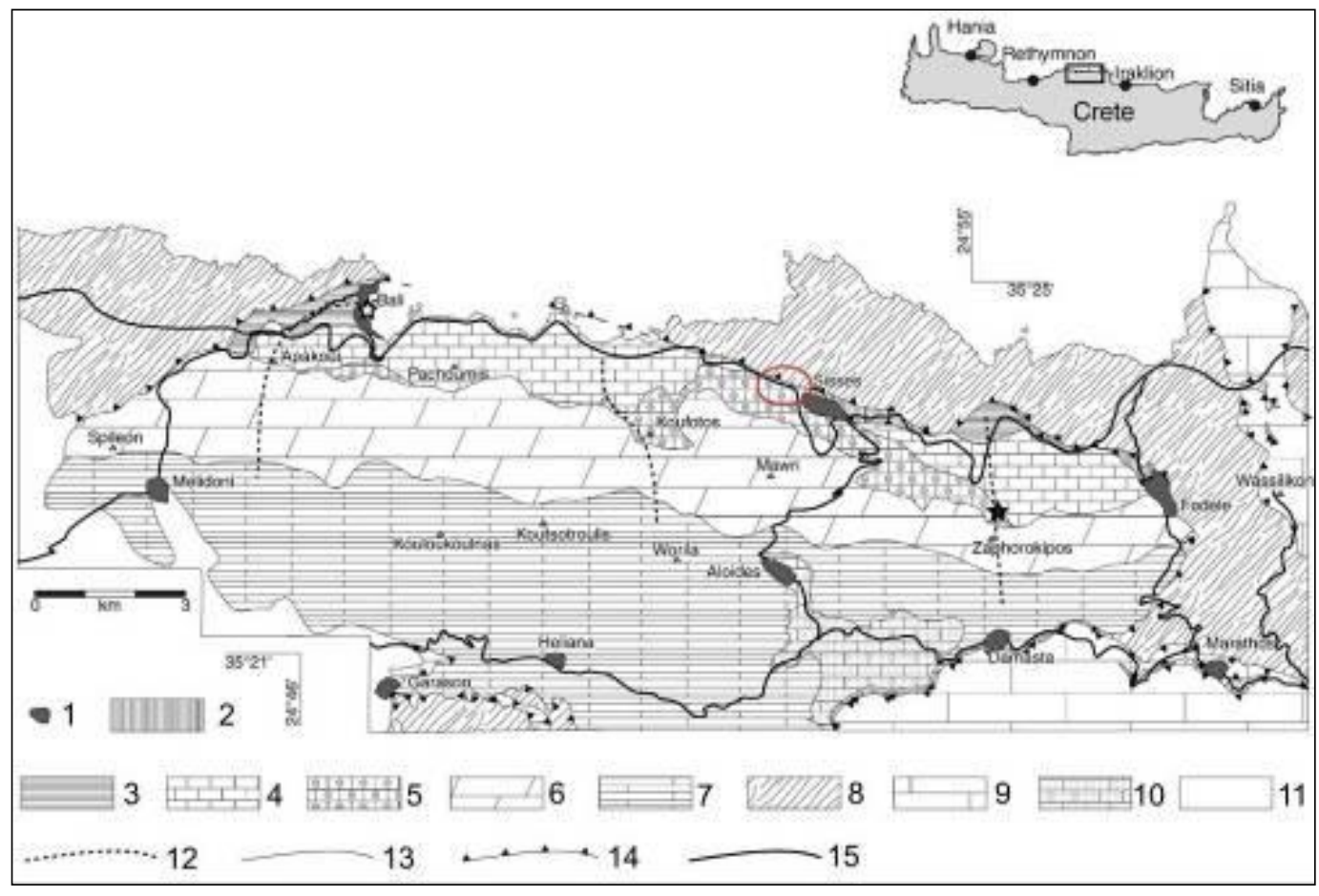

Figure 1 - Geological map of Talaia Ori (after Kock et al., 2007; modified by Epting et al., 1972). (1) Cities (2) Tectonized blocks (slivers), (3) Galinos beds (4) Fodele beds (5) Sisses beds (6) stromatolites-dolomites (7) Plattenkalk group (8) Phyllite-Quartzite nappe (9) Vasilikos marbles (10) red sediments (pre-Tortonio), (11) Tortonio-Pliocene (12) Trace of the stratigraphic section (13) Stratigraphic contact (14) Thrust fault (15) Roads. 

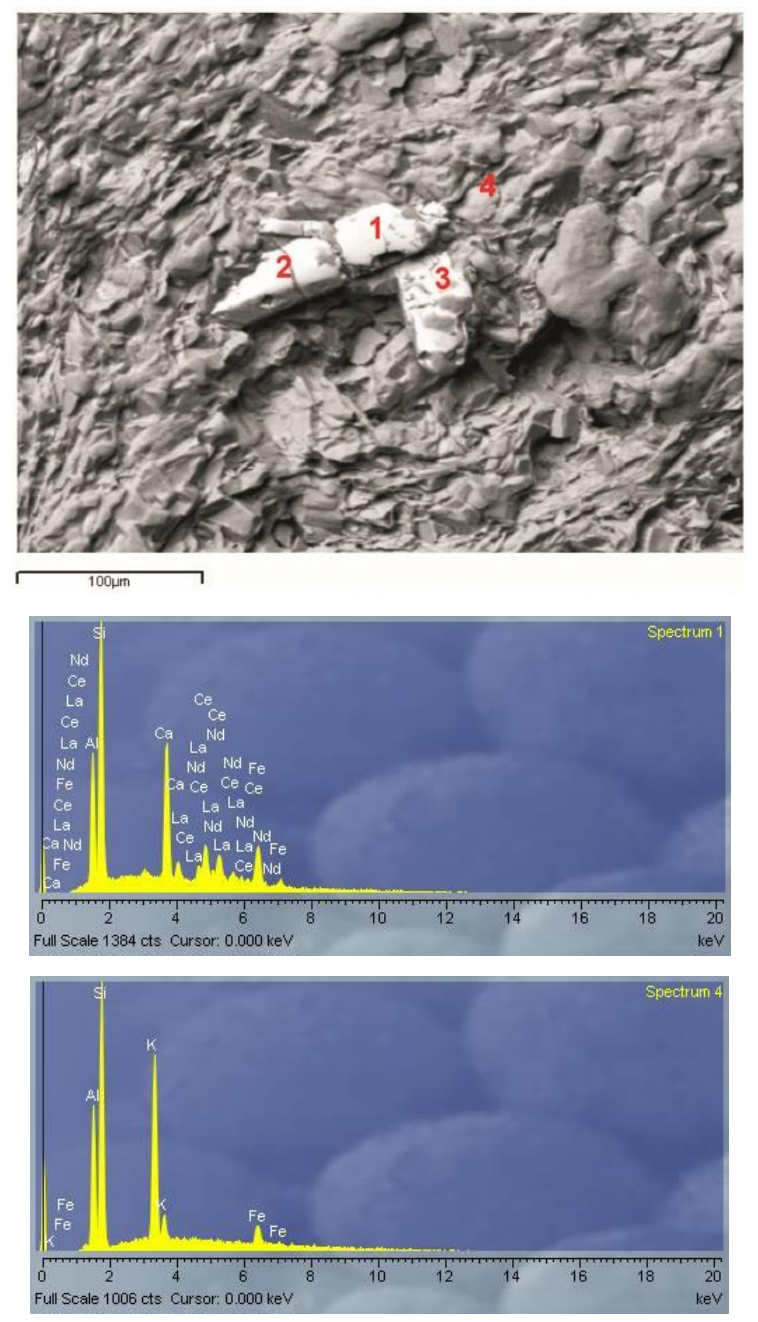

Figure 2 - Backscattered Electron (BSE) image of allanite (1) and mica minerals (4).

\section{Sample preparation - Results}

The original five samples (two metasandstones and three schists) went through crushing (using a jaw crusher) and then grinding in order to reduce their particle size. Next, each sample was homogenised. Using the Mozley hydrocyclon (2"), each homogenized sample was classified in two fractions $<10 \mu \mathrm{m}$ and $>10 \mu \mathrm{m}$. The underflow $(>10 \mu \mathrm{m})$ and overflow $(<10 \mu \mathrm{m})$ of the hydrocyclon were collected separately and dried. Dry-sieving was carried out in the underflow in order to obtain the fractions $(10-212 \mu \mathrm{m})$ and $(212-1000 \mu \mathrm{m})$.

Table 3 includes weight (\%) and concentration in $\mathrm{Ce}$, La of each sample after hydroclassification and dry sieving.

\subsection{Magnetic Separation - Results}

Magnetic separation was conducted in the five original samples for the size fractions $(<10 \mu \mathrm{m}),(10-$ $212 \mu \mathrm{m})$ and $(212-1000 \mu \mathrm{m})$. The fine fraction $(<10 \mu \mathrm{m})$ was separated using the wet high intensity magnetic separator (Carpco), whilst the fractions $(10-212 \mu \mathrm{m})$ and $(212-1000 \mu \mathrm{m})$ were separated using the high intensity induced roll magnetic separator (MIH 111-5, Carpco). The results for each fraction are shown in Tables 4, 5 and 6. 
Table 3 - Results after hydroclassification and dry sieving.

\begin{tabular}{|c|c|c|c|c|}
\hline Sample & Size fraction $(\mu \mathrm{m})$ & Weight (\%) & La (ppm) & Ce (ppm) \\
\hline \multirow{4}{*}{ Metasandstone (1) } & $212-1000$ & 83,48 & 7,95 & 14,56 \\
\hline & $10-212$ & 7,88 & 6,87 & 8,39 \\
\hline & $<10$ & 8,64 & 44,94 & 92,12 \\
\hline & Total & 100,00 & 11,90 & 22,96 \\
\hline \multirow{4}{*}{ Metasandstone (2) } & $212-1000$ & 77,61 & 8,68 & 16,52 \\
\hline & $10-212$ & 6,22 & 8,29 & 13,48 \\
\hline & $<10$ & 16,17 & 26,18 & 47,88 \\
\hline & Total & 100,00 & 10,92 & 19,60 \\
\hline \multirow{4}{*}{ Schist (calc-schist) } & $212-1000$ & 53,26 & 15,12 & 23,80 \\
\hline & $10-212$ & 21,27 & 17,08 & 25,62 \\
\hline & $<10$ & 25,47 & 13,38 & 35,00 \\
\hline & Total & 100,00 & 11,34 & 23,80 \\
\hline \multirow{4}{*}{ Schist (yellow) } & $212-1000$ & 61,92 & 33,32 & 58,10 \\
\hline & $10-212$ & 12,84 & 8,83 & 17,36 \\
\hline & $<10$ & 25,24 & 61,04 & 106,68 \\
\hline & Total & 100,00 & 25,20 & 50,40 \\
\hline \multirow{4}{*}{ Schist (white) } & $212-1000$ & 59,14 & 34,44 & 82,32 \\
\hline & $10-212$ & 15,13 & 46,06 & 104,30 \\
\hline & $<10$ & 25,73 & 12,91 & 47,46 \\
\hline & Total & 100,00 & 37,66 & 84,74 \\
\hline
\end{tabular}

Table 4 - Magnetic separation results for the fine fraction $(<10 \mu \mathrm{m})$.

\begin{tabular}{|c|c|c|c|c|}
\hline \multirow{2}{*}{ Sample } & Product & Weight (\%) & La (ppm) & Ce (ppm) \\
\hline \multirow{4}{*}{ Metasandstone (1) } & Magnetic & 14,38 & 49,70 & 107,80 \\
\cline { 2 - 5 } & Non magnetic & 85,62 & 42,98 & 88,76 \\
\cline { 2 - 5 } & Total & 100,00 & 44,94 & 92,12 \\
\hline \multirow{4}{*}{ Metasandstone (2) } & Magnetic & 7,03 & 39,06 & 94,08 \\
\cline { 2 - 5 } & Non magnetic & 92,97 & 21,00 & 49,42 \\
\cline { 2 - 5 } Schist (calc-schist) & Total & 100,00 & 26,18 & 47,88 \\
\cline { 2 - 5 } & Magnetic & 2,61 & 45,08 & 138,18 \\
\cline { 2 - 5 } & Ton magnetic & 97,39 & 13,80 & 48,30 \\
\hline \multirow{3}{*}{ Schist (yellow) } & Magnetic & 100,00 & 13,38 & 35,00 \\
\cline { 2 - 5 } & Non magnetic & 9,63 & 54,88 & 105,56 \\
\cline { 2 - 5 } & Total & 100,00 & 61,04 & 119,56 \\
\hline \multirow{3}{*}{ Schist (white) } & Magnetic & 1,53 & 152,60 & 358,40 \\
\cline { 2 - 5 } & Non magnetic & 98,47 & 9,49 & 37,80 \\
\cline { 2 - 5 } & Total & 100,00 & 12,91 & 47,46 \\
\hline
\end{tabular}


Table 5 - Magnetic separation results for the fraction (10-212 $\mu \mathrm{m})$.

\begin{tabular}{|c|c|c|c|c|}
\hline Sample & Product & Weight (\%) & La (ppm) & $\mathrm{Ce}(\mathrm{ppm})$ \\
\hline \multirow{4}{*}{ Metasandstone (1) } & Magnetic & 20,73 & 14,36 & 35,91 \\
\hline & Intermediate & 18,91 & 4,94 & 10,28 \\
\hline & Non magnetic & 60,36 & 5,10 & 5,18 \\
\hline & Total & 100,00 & 6,87 & 8,39 \\
\hline \multirow{4}{*}{ Metasandstone (2) } & Magnetic & 36,08 & 13,72 & 26,68 \\
\hline & Intermediate & 19,80 & 7,36 & 8,85 \\
\hline & Non magnetic & 44,12 & 4,05 & 6,99 \\
\hline & Total & 100,00 & 8,29 & 13,48 \\
\hline \multirow{4}{*}{ Schist (calc-schist) } & Magnetic & 17,05 & 27,60 & 54,04 \\
\hline & Intermediate & 28,73 & 15,54 & 25,90 \\
\hline & Non magnetic & 54,22 & 11,37 & 18,20 \\
\hline & Total & 100,00 & 17,08 & 25,62 \\
\hline \multirow{4}{*}{ Schist (yellow) } & Magnetic & 44,33 & 39,74 & 80,31 \\
\hline & Intermediate & 17,17 & 18,90 & 33,32 \\
\hline & Non magnetic & 38,50 & 12,75 & 21,70 \\
\hline & Total & 100,00 & 8,83 & 17,36 \\
\hline \multirow{4}{*}{ Schist (white) } & Magnetic & 21,84 & 108,23 & 230,85 \\
\hline & Intermediate & 21,71 & 39,20 & 93,66 \\
\hline & Non magnetic & 56,45 & 28,42 & 62,86 \\
\hline & Total & 100,00 & 46,06 & 104,30 \\
\hline
\end{tabular}


Table 6 - Magnetic separation results for the fraction $(212-1000 \mu \mathrm{m})$.

\begin{tabular}{|c|c|c|c|c|}
\hline Sample & Product & Weight (\%) & La (ppm) & Ce (ppm) \\
\hline \multirow{4}{*}{ Metasandstone (1) } & Magnetic & 8,50 & 6,35 & 17,66 \\
\cline { 2 - 5 } & Intermediate & 15,50 & 4,56 & 7,90 \\
\cline { 2 - 5 } & Non magnetic & 76,00 & 5,25 & 7,55 \\
\cline { 2 - 5 } & Total & 100,00 & 7,95 & 14,56 \\
\hline \multirow{4}{*}{ Metasandstone (2) } & Magnetic & 19,22 & 10,07 & 17,35 \\
\cline { 2 - 5 } & Intermediate & 21,17 & 3,72 & 12,45 \\
\cline { 2 - 5 } & Non magnetic & 59,61 & 5,66 & 9,98 \\
\cline { 2 - 5 } & Total & 100,00 & 8,68 & 16,52 \\
\hline \multirow{3}{*}{ Schist (calc-schist) } & Magnetic & 2,29 & 28,64 & 71,72 \\
\cline { 2 - 5 } & Intermediate & 7,92 & 17,36 & 24,50 \\
\cline { 2 - 5 } & Non magnetic & 89,79 & 12,56 & 18,06 \\
\cline { 2 - 5 } & Total & 100,00 & 15,12 & 23,80 \\
\hline & Magnetic & 20,76 & 33,44 & 71,78 \\
\cline { 2 - 5 } & Intermediate & 19,11 & 31,78 & 65,66 \\
\cline { 2 - 5 } & Non magnetic & 60,13 & 24,92 & 51,94 \\
\cline { 2 - 5 } & Total & 100,00 & 33,32 & 58,10 \\
\hline \multirow{3}{*}{ Schist (white) } & Magnetic & 16,80 & 73,03 & 165,34 \\
\cline { 2 - 5 } & Intermediate & 15,88 & 33,46 & 70,00 \\
\cline { 2 - 5 } & Non magnetic & 67,32 & 34,16 & 70,00 \\
\cline { 2 - 5 } & Total & 100,00 & 34,44 & 82,32 \\
\hline
\end{tabular}

\section{Conclusions}

The abundance of allanite in the Sisses Beds, strengthens the paleobathymetric/depositional model, which is proposed from Dornsiepen et al. (2001) according to which, the Permian Triassic sequence of the Plattenkalk Group was fine grained, well sorted siliciclastics of a marine deltaic environment, on the southern margin of the Palaeothethys belonging to Gondwana.

Metasandstone (1), metasandstone (2) and yellow schist samples show higher rare earth (Ce, La) concentrations in the fraction $(<10 \mu \mathrm{m})$. Lower rare earth concentrations were found in the fraction $(10-212 \mu \mathrm{m})$ of the metasandstone (1) and the yellow schist. The calc-schist sample does not seem to have notable rare earth concentrations in any fraction. The white schist sample has higher rare earth concentrations in the fraction $(10-212 \mu \mathrm{m})$, and lower concentrations in the fractions (212$1000 \mu \mathrm{m})$ and $(<10 \mu \mathrm{m})$.

The magnetic separation of the fraction $(<10 \mu \mathrm{m})$ showed that the rare earth concentrations are higher in the magnetic products of all the initial samples, except from the yellow schist.

In the fraction (10-212 $\mu \mathrm{m})$ rare earth concentrations are clearly higher in the magnetic products of all samples.

On the other hand, rare earth concentrations in the fraction $(212-1000 \mu \mathrm{m})$ are higher in the magnetic products of metasandstone (1), metasandstone (2) calc schist and white schist, whereas there are no notable concentrations in the yellow schist separation products.

In conclusion, (according to the microscopic and mineral processing data) the optimum grain size for the beneficiation of allanite is $(10-212 \mu \mathrm{m})$. A systematic petrologic study for the understanding of the origin/formation of allanite within the particular metamorphic rocks of the Plattenkalk Group would also provide useful results to optimize the mineral processing methodology. 


\section{References}

Arvanitidis, N. and Goodenough, K., 2014. Unlocking the potential of rare earth resources in Europe, Proc. of the 1st European Rare Earth Resources Conference (ERES2014), Milos, September 2014, 48-56.

Christofides, G., Perugini, D., Koroneos, A., Soldatos, T., Poli, G., Eleftheriadis, G., Del Moro, A. and Neiva, A.M., 2007. Interplay between geochemistry and magma dynamics during magma interaction: An example from the Sithonia Plutonic Complex (NE Greece), Lithos, 95, 243-266.

Dornsiepen, U.F., Manutsoglu, E. and Mertmann, D., 2001. Permian Triassic Palaeogeography of the external Hellenides, Palaeogeography, Palaoeclimatology, Palaeoecology, 172, 327338.

Epting, M., Kudrass, H.R., Leppig, U. and Schafer, A., 1972. Geologie der Talea Ori, Kreta. Neues Jahrbuch fur Geologie und Palaontologie, Monatshefte, 141, 259-285.

Henjes-Kunst, F., Altherr, R., Kreuzer, H. and Hansen, B.T., 1988. Disturbed U-Th-Pb systematics of young zircons and uranothorites: The case of the Miocene Aegean granitoids (Greece), Ghemical Geology (Isotope Geoscience Section), 73, 125-145.

Iliopoulos, I., 2005. Petrogenesis of metamorphic rocks of the island of Ikaria, PhD thesis, Patras, (in greek).

Keay, S., Listerb, G. and Buickc, I., 2001. The timing of partial melting, Barrovian metamorphism and granite intrusion in the Naxos metamorphic core complex, Cyclades, Aegean Sea, Greece, Tectonophysics, 342, 275-312.

Keramidas, K., Voutsas, G., Christofides, G. and Eleftheriadis, G., 2005. Magmatic epidote from the Sithonia pluton (Chalkidiki): comparative geochemistry and crystal structure, Proc. of the $2^{\text {nd }}$ Conference of the Committee of Economic Geology, Mineralogy and Geochemsitry, Thessaloniki, October 2005, 153-161.

Kock, S., Martini, R., Reischmann, T. and Stampfli, G.M., 2007. Detrital zircon and micropalaeontological ages as new constraints for the lowermost tectonic unit (Talea Ori unit) of Crete, Greece, Palaeogeography, Palaeoclimatology, Palaeoecology, 243(3-4), 307321.

Krern, E. and Finger, F., 2007. Formation of monazite and rhabdophane at the expense of allanite during Alpine low temperature retrogression of metapelitic basement rocks from Crete, Greece: Microprobe data and geochronological implications, Lithos, 95, 130-147.

Kotopouli, C.N., Pe-Piper, G. and Katagas, C.G., 1991. The metamorphism and migmatization of the Xanthe-Echinos metamorphic complex, Central Rhodope, Greece, Lithos, 27, 79-93.

Kotopouli, C.N., Pe-Piper, G. and Piper, D.J.W., 2000. Petrology and evolution of the Hercynian Pieria Granitoid Complex (Thessaly, Greece): paleogeographic and geodynamic implications, Lithos, 50, 137-152.

Manutsoglu, E., 1990. Tektonik und Metamorphose der Plattenkalk-Serie im Taygetos (Peloponnes, Griechenland), Berliner geowissenschaftiche Abhandlungen, A 129, 82 pp.

Manutsoglu, E., Soujon, A., Reitner, J. and Dornsiepen, U.F., 1995. Relikte lithistider Demospongiae aus der metamophen Plattenkalk-Serie der Insel Kreta (Griechenland) und ihre palaeobathymetrische Bedeutund, N. Jb. Geol. Palaeont. Mh., 1995/4, 235-247.

Manutsoglu, E., Reitner, J., Mariolakos, D., Bellas, S.M. and Mariolakos, I., 1998. Lithostratigraphische Gliederung und erster Nachweis von Relikten lithistider Demospongiae aus der Plattenkalk-Gruppe des Taygetos Gebirges, Peloponnes/Griechenland, Zeitschrift der Deutschen Geologischen Gesellschaft, 149, 91-103.

Manutsoglu, E., Soujon, A. and Jacobshagen, V., 2003. Tectonic structure and fabric development of the Plattenkalk unit around the Samaria gorge, Western Crete, Greece, Zeitschrift der Deutschen Geologischen Gesellschaft, 154(1), 85-100.

Manutsoglu, E., 2008. Allanite-bearing metamorphic sequence in Talea Ori, central Crete, Greece, - Abstract and Poster, 86. Annual DMG Meeting 14 -17 September 2008, Berlin, Abstract CD. 
Mastrakas, N., 2006. Tinos pluton and associated skarn formations, PhD Thesis, Univ. Patras, 227 pp. (in Greek).

Melfos, V. and Voudouris P.Ch., 2012. Geological, Mineralogical and Geochemical Aspects for Critical and Rare Metals in Greece, Minerals, 2, 300-317.

Mezger, K. and Okrusch, M., 1985. Metamorphism of the Variegated Sequence at Kallithea, Samos, Greece, TMPM Tschermaks Min. Petr. Mitt., 34, 67-82.

Miller, D.P., Marschall, H.R. and Schumacher, J.C., 2009. Metasomatic formation and petrology of blueschist-facies hybrid rocks from Syros (Greece): Implications for reactions at the slabmantle interface, Lithos, 107, 53-67.

Mitropoulos, P., 1987. Primary allanite in andesitic rocks from the Poros Volcano, Greece, Mineralogical Magazine, October 1987, 51, 601-604.

Mposkos, E., Perraki, M. and Palikari, S., 2009. Single and multiphase inclusions in metapelitic garnets of the Rhodope Metamorphic Province, NE Greece, Spectrochimica Acta, Part A, 73, 477-483.

Papadopoulos, A., Christofides, G., Pe-Piper, G., Koroneos, A. and Papadopoulou, L., 2015. Geochemistry of beach sands from Sithonia Peninsula (Chalkidiki, Northern Greece), Mineralogy and Petrology, 109(1), 53-66.

Perdikatsis, V. and Papastavrou, S., 1993. Non-metamict allanite from Serifos Island, Cyclades (Greece), Bull. Geol. Soc. Greece, XXVIII/2, 13-21, Athens, 1993.

Pe-Piper, G., Piper, D.J.W. and Matarangas, M., 2002. Regional implications of geochemistry and style of emplacement of Miocene I-type diorite and granite, Delos, Cyclades, Greece, Lithos, 60 47-66.

Putlitz, B., Cosca, M.A. and Schumacher, J.C., 2005. Prograde mica 40Ar/39Ar growth ages recorded in high pressure rocks (Syros, Cyclades, Greece), Chemical Geology, 214, 79-98.

Šarić, K., Cvetković, V., Romer R.L., Christofides, G. and Koroneos, A., 2009. Granitoids associated with East Vardar ophiolites (Serbia, F.Y.R. of Macedonia and northern Greece): Origin, evolution and geodynamic significance inferred from major and trace element data and $\mathrm{Sr}-\mathrm{Nd}-\mathrm{Pb}$ isotopes, Lithos, 108, 131-150.

Soujon, A., Manutsoglu, E., Reitner, J. and Jacobshagen, V., 1995. Lithistide Demospongiae aus der metamorphen Plattenkalk-Serie der Trypali Ori (Kreta/Griechenland), Berliner geowissenschaftiche Abhandlungen, E16, 559-567. 